\title{
EFFECTIVENESS OF TWO STAY TWO STRAY LEARNING METHODS AT ISLAMIC EDUCATION (PAI) SUBJECTS TO IMPROVE LEARNING OUTCOMES OF STUDENTS OF SMK DWI PUTRI HUSADA, BOGOR CITY
}

\author{
Ridwan Hadi Pratama ${ }^{\text {a)}}$, Hidayah Baisa ${ }^{\text {a) }}$ \\ a) Universitas Ibn Khaldun, Bogor, Indonesia \\ Corresponding Author: ridwanpratama1411@gmail.com
}

Article history: received 25 January 2019; revised 15 February 2019; accepted 21 February 2019

\begin{abstract}
This research is a classroom action research, conducted collaboratively between researchers and collaborators. The purpose of this study was to improve the learning outcomes of Islamic Education (PAI) subjects in class X students using Two Stay Two Stray Learning Method (TSTS). The object of this research was students of the SMK Dwi Putri Husada in Bogor City consisting of 43 students. This research was conducted in the odd semester of the academic year 2017/2018. The results showed that the average value of PAI subjects in the first cycle obtained mastery learning outcomes of $44.19 \%$, learning outcomes in the second cycle obtained completeness of learning outcomes by $86.04 \%$. While in the third cycle obtained the completeness of learning outcomes of $91.4 \%$. the quality of learning implementation in the first cycle obtained a value of 69 and in the second cycle increased to 81. And in the third cycle increased to 90 . Based on the results of the study it can be concluded that the Two Stay Two Stray learning method can improve student learning outcomes in class X in SMK Dwi Putri Husada, Bogor City. In addition, the Two Stay Two Stray learning method can increase the activity, cooperation, and courage of students in the learning process.
\end{abstract}

Keywords: Learning Outcomes, Islamic Education, Two Stay Two Stray

\section{INTRODUCTION}

Education is a way to seek knowledge, with human education easier to get any information, both formal and informal. Education consists of teachers and students. If there are 2 elements, then education will run.

Education can not be separated from the performance of teachers, teachers are required to bring lessons so that they can be easily accepted by students so that it becomes an information or knowledge. But unfortunately, there are still many teachers who do not understand their own duties. What they understand is only limited to carrying out tasks, transferring knowledge to students without any interaction between students and teachers.

According to the Indonesian Law (Chapter 1, Article 1) "Education is a conscious and planned effort to create a learning atmosphere and learning process so that students actively develop their potential to have religious spiritual strength, self-control, personality, intelligence, noble character and skills needed by himself, society, nation and state ".

Education is a place to study, this is in line with the word of God Q.S Al-Mujadalah verse 11:

Which means: O believers! When it is said to you, "Give spaciousness in the assemblies," then expose, surely God will give spaciousness to you. And if it is said, "Stand ye," then stand up, surely Allah will raise (degrees) those who believe among you and those who are given some degree of knowledge. And Allah is careful of what you do"
From the above verse, an outline can be drawn that science can increase one's degree, knowledge can be obtained through education, whether formal or informal. In the verse it means that education is the most important element in living life. when someone wants to get the world education is one of the keys.

The world of education will definitely not be separated from the learning process. The learning process consists of students and teachers where the teacher becomes an educator who will make students become products that are quality for the progress of the country. However, in the reality of the learning process there must be problems, the problems faced will not be separated from the learning itself. One of the problems in national education in Indonesia is the study of Islamic Education (PAI)

According to Daulay in his book (Islamic Education in Islamic perspective, 30) PAI is one of the most important fields of study at all levels of education consisting of religious elements to foster the faith and piety of students. Where PAI must be able to make students more religious in living their daily lives. "PAI is a field of study carried out to develop all human potential both physically and mentally to form a complete Muslim person".

The importance of PAI in the mastery and development of Faith and Faith requires the development and mastery of students towards Islamic religious education. The process of development and mastery of Islamic education must start from an early age. But in reality, in the field there are still many 
students who do not like PAI subjects. For them PAI is a boring subject, resulting in a lack of enthusiasm and motivation for students to take part in PAI learning. In addition, another tangible result of the lack of enthusiasm and motivation of students in participating in PAI learning is that there are still low student learning outcomes in PAI learning.

During this time the learning activities that dominated the PAI classes were using the lecture method, where the teacher was more active and dominating in the classroom, while the students were just silent and listening to the teacher's long and wide explanation. This kind of learning is felt to pay little attention to activities, interactions and constructional knowledge by students, so that there are various negative assumptions of students regarding PAI learning. In addition, the lack of use of media by teachers so that students feel bored when implementing classroom learning.

One learning model that is innovative and can eliminate student boredom is Two Stay Two Stray. In the TSTS learning model students are required to be active in learning. The role of the teacher in TSTS is as a facilitator and motivator. TSTS is expected to be able to make students more active and can easily understand every material that is learned. "The method of two stay two stray or the method of two stays and two guests. Learning with this method begins with the division of groups. After the group is formed the teacher shares the task in the form of problems that they must discuss the answer. (Suprijono [1]).

The TSTS learning model is a model that promotes collaboration between students formed with groups, where students must discuss in solving a problem. This is in line with the word of God in the letter An-Nahl verse 125 which means as follows:

Call upon the people of your way with good wisdom and teaching, and argue with them in a good way. Verily, your Lord, He is the one who knows more who is astray from His path and He who knows better who gets the guidance.

From the above paragraph can be concluded that the teacher must be able to carry out learning well, arguing in the sense of discussing with others is a way to solve problems properly. As expressed by Susanto in his book that "discussion is used to explore, solve, and develop ideas through question and answer and statements of opinion, either guided or open.

In the learning process of Islamic Education at the SMK Dwi Putri Husada (DPH) in Bogor City, especially students of class $\mathrm{X}$ showed that students' learning outcomes were still low on PAI subjects. This can be seen from the results of observations with the teacher that the daily test scores, the initial reflection test scores that have been carried out on PAI subjects do not meet the criteria, with the Minimum Completeness Criteria PAI is 70. Students who have reached KKM are 13 students $(30,23 \%)$ and 30 students $(69.77 \%)$ have not yet reached KKM. In addition, PAI learning activities in the classroom rarely use innovative learning model models. This causes students still often feel bored when studying PAI subjects.

Based on this, the researcher found a problem in PAI learning, so the TSTS Learning model was used in the learning process to create an active, creative and fun learning atmosphere so that the KKM was reached.

The researcher was interested in conducting Classroom Action Research (CAR) as an effort to improve the learning process and improve student learning outcomes with the title Effectiveness of Two Stay Two Stray learning model in improving student learning outcomes in Islamic Education subjects, case study of SMK Dwi Putri Husada (DPH) in Bogor City.

As expressed by Suprijono [1] "Mills argues that the Learning model is an accurate form of representation as an actual process that allows a person or group of people to try to act on the model. The model is an interpretation of the results of observations and measurements obtained from several systems.

According to arends cited by Suprijono [1] the learning model refers to the approach that will be used, including the learning objectives, the stages in learning activities, the learning environment, and classroom management.

The development of a learning model is very dependent on the characteristics of subjects or subject matter so that there is no particular learning model that is believed to be the best learning model, all depending on the situation and conditions. The term learning model has many broader meanings than strategies, methods, or procedures. "The learning model has 4 special characteristics that are not possessed by methods, strategies or procedures. These characteristics include:

1. Logical theoretical rationales compiled by the creators or developers

2. The foundation of thinking about what and how students learn

3. Teaching behavior is needed so that the model can be implemented successfully

4. The learning environment needed so that the learning objectives can be achieved. (Fathurrahman [2])

From the opinion above, the writer can conclude that the understanding of learning models is a conceptual framework that describes a systematic procedure in organizing learning experiences to achieve learning goals.

According to Suyanto, the TSTS learning model is by way of students sharing knowledge and experience with other groups. The syntax is group work, two students come to another group and two other students remain in the group to receive two people from another group, group work, return to the initial group, group work, and group reports.

According to (Suprijono [1]), "the cooperative learning model of the TSTS type or two living two 
guests begins with the division of groups. After groups are formed, the teacher gives the task of problems that they must discuss the answer to. After the group intra discussion was completed, two people from each group left the group to visit other groups. Group members who do not get assignments as ambassadors (guests) have an obligation to receive guests from other groups. Their job is to present the results of the group discussion to the guest. Two people serving as guests are required to visit other groups. If they have carried out their duties, they return to their original group. After returning to the original group, both students who visited or received guests matched and discussed the work they had done.

As every approach, strategy and method of learning, on the one hand has various advantages but also has disadvantages or difficulties.

Likewise with the TSTS method, as revealed by Shoimin [3], namely:

a) The advantages of the TSTS method are:

1) Easy to break into pairs.

2) More tasks that can be done.

3) Teachers easily monitor.

4) Can be applied to all classes / levels.

5) The tendency of student learning to be more meaningful.

6) More oriented to activity.

7) It is expected that students will dare to express their opinions.

8) Add cohesiveness and confidence to students.

9) Students' speaking abilities can be improved.

10)Helps increase learning interest and achievement. In addition to expressing the advantages of the TSTS method, Shoimin [3] also revealed the shortcomings of the TSTS method, namely:

b) Disadvantages of the TSTS Method are:

1) Requires a long time.

2) Students tend to not want to study in groups.

3) For teachers, it requires a lot of preparation (material, funds, and energy).

4) Teachers tend to have difficulties in class management.

5) Requires good socialization.

6) Even numbers can make it difficult for groups to be grouped.

7) Students easily break away from involvement and do not pay attention to the teacher.

8) Lack of opportunities to pay attention to the teacher.

Shoimin [3] revealed that the steps of the TSTS method are 4 steps, namely:

1. Students work together in groups of four as usual.

2. After completion, two students from each group will leave the group and each visit to another group.

3. Two students who live in groups are assigned to share their work and information with their guests.

4. Match groups and discuss the results of their work.

Dimyati and Mudjiono [4] suggest that learning outcomes are things that can be viewed from two sides, namely the student's side and the teacher's side. Learning outcomes are a better level of mental development compared to before learning.

Arifin [5] presents the following objectives of learning outcomes:

1. To find out the level of student mastery of the material that has been given.

2. To know the skills, motivations, talents, interests, and attitudes of students towards the learning program.

3. To determine the level of progress and suitability of student learning outcomes with standard competencies and basic competencies that have been set.

4. To diagnose the advantages and disadvantages of students in participating in learning activities. Student excellence can be used as a basis for teachers to provide further guidance and development, while weaknesses can be used as a reference to provide assistance or guidance.

5. For selection, namely choosing and determining students who are in accordance with certain types of education.

6. To determine the grade increase.

7. To place students according to their potential.

Referring to Gagne's thought in Suprijono [1] learning outcomes in the form of:

1) Verbal information that is capability to express knowledge in the form of language, both oral and written. The ability to respond specifically to specific stimuli. This ability does not require symbol manipulation, problem solving or application of rules.

2) Intellectual skills, namely the ability to present concepts and symbols. Intellectual skills consist of the ability to categorize, analytical abilities-synthesis of concepts and develop scientific principles. Intellectual skills are the ability to carry out cognitive activities that are typical.

3) Cognitive strategies, namely the ability to channel and direct cognitive activities themselves. This capability includes the use of concepts and rules in solving problems.

4) Motor skills, namely the ability to carry out a series of physical movements in affairs and coordination, so as to realize the automatism of physical motion.

5) Attitude is the ability to accept or reject objects based on an assessment of the object. Attitude is the ability to make values as standards of behavior.

Slameto in Tampubolon [6] explains that the factors that influence learning outcomes can be divided into two groups, namely, the factors that exist in the students themselves which include:

1. Biological factors, which include health, nutrition, hearing, and vision. If one biological factor is disturbed. This will affect learning outcomes.

2. Psychological factors that include intelligence, interests and motivations, and attention to thinking memories. 
3. Factors of fatigue which include physical and spiritual fatigue. Physical exhaustion with weakness, hunger, thirst and sleepiness. While spiritual fatigue can be seen with the presence of lethargy and boredom so that the interest and drive to produce something will disappear.

Factors that exist outside the individual are called external factors including:

1) Family factors, namely the first and foremost educational institutions. Educational institutions are small in size but are decisive for education in large sizes.

2) School factors, which include curriculum teaching methods, teacher relations with students, students with students, and discipline at school.

3) Community factors, which include the form of life of the surrounding community that can influence student achievement. If the student's learning environment is learned, it will be affected and encouraged to learn more.

The word education comes from the word "educator", or in English is called "to educate" which means teaching or helping someone learn. As expressed by Agus Basari quoted by Engku and Zubaidah saying "education is an effort to encourage and help a person develop all his potential and change himself, from one quality to another higher quality.

This is in line with the expression H. Arifin quoted by Zubaidah and Engku that "Islamic education is intended to achieve a balance of personal, human growth as a whole through psychological exercises, reason, intelligence, feelings, and the five senses. Therefore, Islamic education must develop all aspects of human life, both spiritual, intellectual, imagination, Ottoman, scientific, language, both individually and in groups and encourage those aspects towards the good and the achievement of the perfection of life "

Whereas according to Haidar in his book arguing about the purpose of Islamic education is, "the aim of Islamic education is closely related to the goal of creating humans as caliphs and as" Abdu Allah. "

Haidar also cited the description of the purpose of the education presented by Atiyah Al-Abrasyi as follows:

1. Helping noble moral formation.

2. Preparation for the life of the world and the hereafter

3. Growing the spiritual spirit (Sceintific Spirit)

4. Prepare students in terms of professionals

5. Preparation to seek sustenance.

\section{RESEARCH METHODS}

This research is a type of Classroom Action Research through the following design:

1. Research Place

Conducted at Dwi Putri Husada Health Vocational School, Bogor City, in the $\mathrm{X}$ class, amounting to 43 students.

\section{Research Time}

This Classroom Action Research was conducted in April 2018 to May 2018 Even semester 2017/2018 Academic Year.

Table 1. Implementation of Research 3 Cycles

\begin{tabular}{|c|c|c|c|c|c|}
\hline No & Date & Time & $\begin{array}{c}\text { Action } \\
\text { Event }\end{array}$ & Student & Information \\
\hline 1. & $\begin{array}{c}10 / 5 / \\
2018\end{array}$ & $\begin{array}{c}08.00- \\
09.25\end{array}$ & $\begin{array}{c}\text { Cycle } \\
1\end{array}$ & 43 & $\begin{array}{c}\text { Collaborator } \\
1 \text { PAI teacher }\end{array}$ \\
\hline 2. & $\begin{array}{c}24 / 5 / \\
2018\end{array}$ & $\begin{array}{c}08.00- \\
09.25\end{array}$ & $\begin{array}{c}\text { Cycle } \\
2\end{array}$ & 43 & $\begin{array}{c}\text { Collaborator } \\
1 \text { PAI teacher }\end{array}$ \\
\hline 3 & $\begin{array}{c}14 / 1 / \\
2019\end{array}$ & $\begin{array}{c}08.00- \\
09.25\end{array}$ & $\begin{array}{c}\text { Cycle } \\
3\end{array}$ & 43 & $\begin{array}{c}\text { Collaborator } \\
1 \text { PAI teacher }\end{array}$ \\
\hline
\end{tabular}

3. Research Subjects.

The research subjects were class $\mathrm{X}$ students of SMK Dwi Putri Husada with 43 students.

\section{RESULTS AND DISCUSSION}

Cycle I

1) Data on the Assessment Results of Cycle I Learning Implementation

From the results of observations made by the two collaborators on the implementation of the learning can be seen in Table 2 as follows:

Table 2. Results of Process Improvement Assessment Cycle I Learning

\begin{tabular}{|c|c|c|}
\hline Collaborator & Final Score & Interpretation \\
\hline I & 68 & good \\
\hline
\end{tabular}

Table 2. shows that the improvement of the learning process in the first cycle obtained a value of 68 . This can be seen from the results of the collector's assessment which gives a value of 68 with a fairly good interpretation. For more details, see the graph as follows:

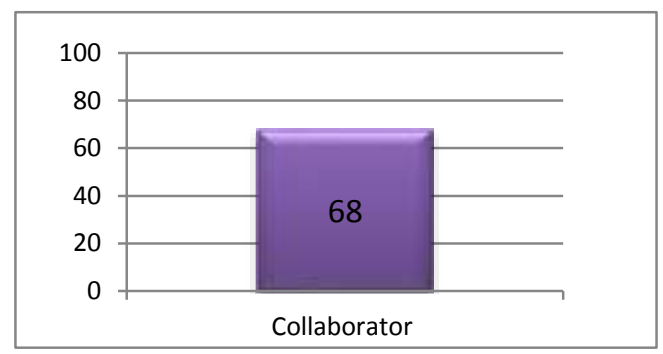

Figure 1. Histogram Diagram Results of Evaluation of Cycle I Learning Process Improvement

2) Data on Results of Student Behavior Improvement in Cycle I

Assessment of improvement in student behavior during learning is something observed by collaborators when the learning process takes place. The results of improving the behavior of class X students of SMK Dwi 
Putri Husada, Tanah Sareal District, Bogor City, during the learning cycle I can be seen in Table 3 below:

Table 3 Observation Results of Behavior Improvement Student Cycle I

\begin{tabular}{|c|c|l|}
\hline Goup & Collaborator & Interpretation \\
\hline 1 & 68 & Pretty good \\
\hline 2 & 68,2 & Pretty good \\
\hline 3 & 70 & Pretty good \\
\hline 4 & 67,2 & Pretty good \\
\hline Total & 273,4 & \\
\hline
\end{tabular}

Based on Table 3, it is explained that Group 1 gets a score of 68 with quite good interpretation, group 2 with a value of 68.2 with quite good interpretation, group 3 with 70 with quite good interpretation, group 4 with an average of 67.2 with quite good interpretation. To be more clear about improving the behavior of class $\mathrm{X}$ students at SMK Dwi Putri Husada, Tanah Sareal District, Bogor City, during the learning process, the first cycle can be seen in the histogram diagram below:

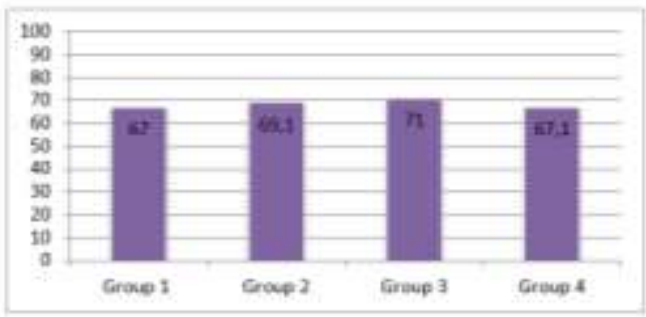

Figure 2. Histogram Diagram Improving Student Cycle I Behavior

Based on Figure 2, it can be seen that group 3 obtained the highest value of activity change with a value of 71 with good interpretation. Whereas the change in activity with the lowest value was in group 1 with a value of 67 with good interpretation, thus needed improvement in the next learning process so students were more active in learning and changes in student activities were getting very good.

\section{3) Cycle I Learning Outcome Data}

The assessment of the first cycle was attended by all class X students of SMK Dwi Putri Husada, Tanah Sareal District, Bogor City, which totaled 43 students. From the implementation of the assessment of the first cycle, the learning outcomes of the first cycle were obtained, namely as follows:

Table 4 Completeness of Cycle I Learning Outcomes

\begin{tabular}{|c|c|c|}
\hline $\begin{array}{c}\text { Complete Learning } \\
\text { Outcomes }\end{array}$ & Student & $\begin{array}{c}\text { Percentage } \\
(\%)\end{array}$ \\
\hline Completed & 19 & $44,19 \%$ \\
\hline Not Completed & 24 & $55,81 \%$ \\
\hline Total & 43 & $100 \%$ \\
\hline
\end{tabular}

Based on Table 4 it is known that of the 43 students who took the assessment of the first cycle there were 19 students who had achieved the minimum completeness criteria (KKM) or by $44.19 \%$, while the students who had not completed were 24 students or $55.81 \%$. The average value is still below the KKM, this shows that the completeness of classical learning outcomes has not reached a minimum indicator of research success of $85 \%$ with a KKM of 70 . The data can be clarified through the following histogram diagram:

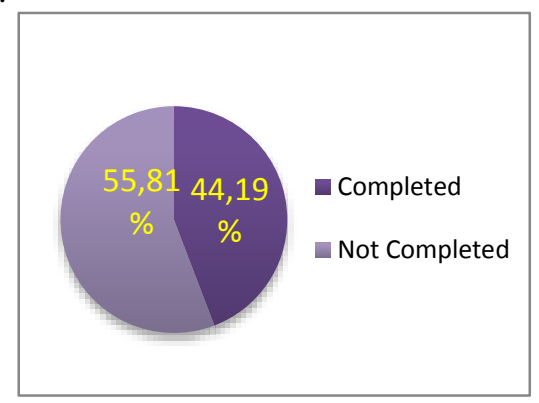

Figure 3. Pie Chart Chart of Learning Completion Results Cycle I

In Figure 3 it is known that the completeness of the learning outcomes of PAI material subjects avoids despicable behavior in the first cycle as many as 19 students or $44.19 \%$ who have reached the KKM score. While 24 students or $55.81 \%$ have not yet reached the KKM score. For more details, it will be presented in the frequency distribution table using the Sturgess calculation rules, as follows: $47=42$

Range $(\mathrm{R})=$ highest value - lowest value $=89$ -

$$
\begin{aligned}
\text { Many classes }(\mathrm{k}) & =1+3,3(\log \mathrm{n}) \\
& =1+3,3(\log 43) \\
& =1+3,3(1,63) \\
& =6,37=6
\end{aligned}
$$

Class length $(\mathrm{p})=\frac{\text { Range }(R)}{\text { Many classes }(K)}=\frac{42}{6}=7$

Table 5. Data Frequency Distribution of Student Cycle I Learning Outcomes

\begin{tabular}{|c|c|c|c|c|c|}
\hline No & $\begin{array}{c}\text { Class } \\
\text { Interval }\end{array}$ & $\begin{array}{c}\text { Class } \\
\text { Boundary }\end{array}$ & Midpoint & $\mathrm{f}_{\text {absolut }}$ & $\begin{array}{c}f_{\text {relatif }} \\
(\%)\end{array}$ \\
\hline 1 & $47-53$ & $46,5-53,5$ & 50 & 4 & 9 \\
\hline 2 & $54-61$ & $53,5-61,5$ & 57,5 & 6 & 14 \\
\hline 3 & $62-69$ & $61,5-69,5$ & 65,5 & 14 & 33 \\
\hline 4 & $70-76$ & $69,5-76,5$ & 73 & 3 & 7 \\
\hline 5 & $77-83$ & $76,5-83,5$ & 80 & 6 & 14 \\
\hline 6 & $84-90$ & $83,5-90,5$ & 87 & 10 & 23 \\
\hline \multicolumn{7}{|c|}{ Jumlah } & 43 & 100 \\
\hline
\end{tabular}

Based on Table 5 shows that of the 43 grade $X$ students of Dwi Putri Husada Vocational School in Tanah Sareal District, Bogor City, which were in the 4753 interval as many as 4 students, in the 54-61 interval as many as 6 students, at intervals $62-69$ as many as 14 students, at 70-76 as many as 3 students, at 77-83 intervals of 6 students, and at 84-90 intervals as many as 10 students. The completeness of student learning outcomes in the first cycle is as many as 19 students or 
$44.19 \%$, while those that have not been completed there are 24 students or $55.81 \%$. This shows that the completeness of learning in a classical manner has not yet reached the minimum research success criteria of $85 \%$.

\section{Cycle II}

1) Data on the Assessment Results of Cycle II Learning Based on the results of observations conducted by the collaborator on the implementation of the second cycle of learning, can be seen in Table 6.

Table 6. Results of Improvement Assessment Cycle II Learning Process

\begin{tabular}{|c|c|c|}
\hline Collaborator & Final Score & Interpretation \\
\hline I & 85 & good \\
\hline
\end{tabular}

Based on Table 6 above, it can be seen that the process of implementing learning in the second cycle increased. Kolabolator gives a value of 85 with good interpretation. So that it is obtained. For more details the results of the implementation of learning can be seen in Figure diagram 4 below:

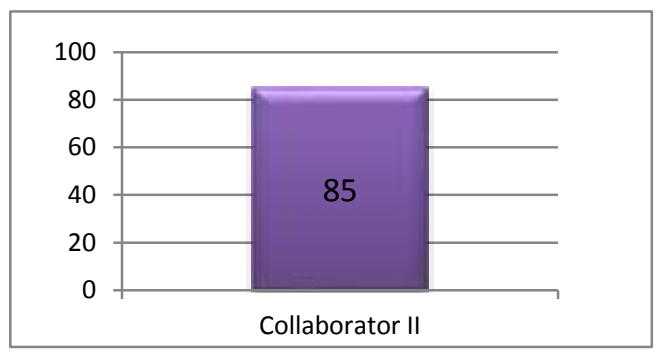

Figure 4. Histogram Diagram Assessment of Improvement of Cycle II Learning Implementation

2) Data on Results of Student Behavior Improvement in Cycle II

Assessment of improvement in student behavior during learning is observed by observers when the learning process takes place. The results of the improvement in behavior of class $X$ students of SMK Dwi Putri Husada in Tanah Sareal District, Bogor City during learning can be seen in Table 7 below:

Table 7. Results of Observation on Behavior Improvement Student Cycle II

\begin{tabular}{|c|c|c|}
\hline Group & Collaborator & Interpretation \\
\hline 1 & 86,2 & Pretty good \\
\hline 2 & 87,2 & Pretty good \\
\hline 3 & 87 & Pretty good \\
\hline 4 & 84,4 & Pretty good \\
\hline
\end{tabular}

Based on Table 7, it can be explained that group 1 gets a score of 86.2 with good interpretation, group 2 with a value of 87.2 with good interpretation, group 3 with a value of 87 with good interpretation, group 4 with a value of 84.4 with good interpretation. To be more clear about improving the behavior of class $\mathrm{X}$ students at SMK Dwi Putri Husada, Tanah Sareal District, Bogor, during the learning process in cycle II can be seen in the histogram diagram below:

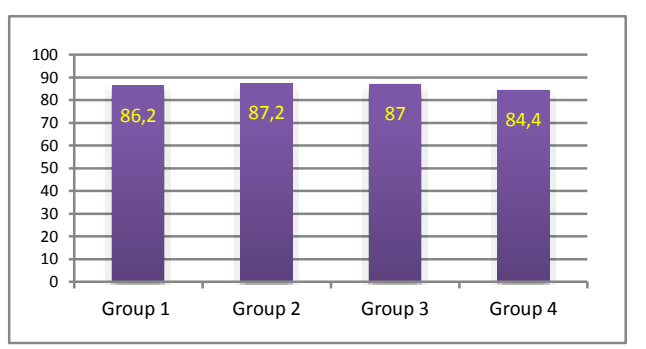

Figure 5. Histogram Diagram Improving Student Behavior in Cycle II

Based on Figure 5 above, it can be seen that the highest student behavior change assessment is given to group 2 with the acquisition of a value of 87.2 included in good interpretation.

\section{3) Cycle II Learning Outcome Data}

Assessment of cycle II was followed by all students of class X of SMK Dwi Putri Husada in Tanah Sareal District, Bogor City, which totaled 43 students. From the implementation of the second cycle of assessment, the learning outcomes of the second cycle were obtained, namely as follows:

Table 8. Completeness of Cycle II Learning Outcomes

\begin{tabular}{|c|c|c|}
\hline $\begin{array}{c}\text { Complete Learning } \\
\text { Outcomes }\end{array}$ & Student & Persentage (\%) \\
\hline Complete & 37 & 86,04 \\
\hline Not Completed & 6 & 13,96 \\
\hline Total & 43 & 100 \\
\hline
\end{tabular}

Based on Table 8 it is known that the completeness of student learning outcomes in the second cycle has increased compared to the completeness of student learning outcomes in the first cycle and has exceeded the research success criteria, namely 37 students who have reached the minimum completeness criteria (KKM) or $86.04 \%$ complete, while students who have not completed as many as 6 students or by $13.96 \%$ the average value obtained in the assessment of the second cycle has also exceeded the KKM, namely 80.20.

\section{Cycle III}

1) Data on the Assessment Results of Cycle III Learning Implementation

Based on the results of observations conducted by the collaborator on the implementation of learning cycle III, it can be seen in Table 9. as follows:

Table 9. Results of Improvement Assessment Cycle III Learning Process

\begin{tabular}{|c|c|c|}
\hline Collaborator & Final Score & Interpretation \\
\hline I & 90 & Very good \\
\hline
\end{tabular}


Based on Table 9. above, it can be seen that the process of implementing learning in the third cycle increased. Kolabolator gives a value of 90 with good interpretation. So that it is obtained. For more details the results of the implementation of learning can be seen in Figure diagram 6 below:

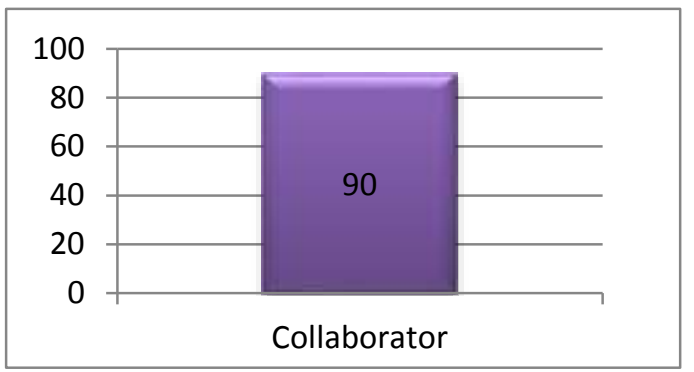

Figure 6. Histogram Diagram Assessment of Improvement of Cycle III Learning Implementation

2) Data on Results of Student Behavior Improvement in Cycle III

Assessment of improvement in student behavior during learning is observed by observers when the learning process takes place. The results of the improvement in behavior of class X students of SMK Dwi Putri Husada in Tanah Sareal District, Bogor City during learning can be seen in Table 10 below:

Table 10. Results of Observation on Behavior Improvement Student Cycle III

\begin{tabular}{|c|c|l|}
\hline Group & Collaborator & Interpretation \\
\hline 1 & 88,2 & Pretty good \\
\hline 2 & 90 & Pretty good \\
\hline 3 & 92 & Pretty good \\
\hline 4 & 86,2 & Pretty good \\
\hline
\end{tabular}

Based on Table 10, it can be explained that group 1 gets a score of 88.2 with very good interpretation, group 2 with a value of 90 with very good interpretation, group 3 with a value of 92 with very good interpretation, group 4 with a value of 86.2 with very good interpretation. To be more clear about improving the behavior of class X students at SMK Dwi Putri Husada, Tanah Sareal District, Bogor, during the learning process in cycle II can be seen in the histogram diagram below:

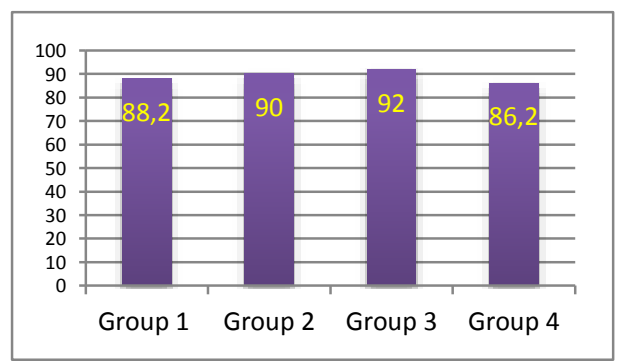

Figure 7. Histogram Diagram Improving Student Behavior in Cycle II
Based on Figure 7. above, it can be seen that the highest student behavior change assessment was given to group 3 with the acquisition of 92 included in the excellent interpretation.

\section{3) Cycle III Learning Outcome Data}

Assessment of cycle III was followed by all class X students of SMK Dwi Putri Husada, Tanah Sareal District, Bogor City, which totaled 43 students. From the implementation of the third cycle of assessment, the learning outcomes of the second cycle were obtained, namely as follows:

Table 11. Completeness of Cycle II Learning Outcomes

\begin{tabular}{|c|c|c|}
\hline $\begin{array}{c}\text { Complete Learning } \\
\text { Outcomes }\end{array}$ & Student & $\begin{array}{c}\text { Percentage } \\
(\%)\end{array}$ \\
\hline Completed & 41 & 91,4 \\
\hline Not Completed & 2 & 8,6 \\
\hline Total & 43 & $100 \%$ \\
\hline
\end{tabular}

Based on Table 11, it is known that the completeness of student learning outcomes in the third cycle has increased compared to the completeness of student learning outcomes in the second cycle and has exceeded the research success criteria, there are 41 students who have reached the minimum completeness criteria (KKM) or $91.4 \%$ complete, while students who have not completed as many as 2 students or equal to $8.6 \%$ the average value obtained in the assessment of cycle III has also exceeded the KKM, which is 89.6.

\section{CONCLUSION}

Based on the discussion of the results of the research that has been conducted, it can be concluded that the application of the Two Stay Two Stray learning model can improve the learning outcomes of class $\mathrm{X}$ PAI subjects at the Dwi Dwi Husada Vocational School in Tanah Sareal District, Bogor City, the semester of the school year 2017/2018.

The above conclusions are in accordance with the results of the study as follows:

1. Improving the quality of learning implementation in the first cycle obtained a score of 69 and in the second cycle increased to 86 including in the good interpretation and in the third cycle increased to 90 .

2. Changes in student behavior that appear to include activeness, cooperation, and courage. Students also experience an increase, in the first cycle the average value of student behavior is 68.50 and in the second cycle the average value of student behavior increases to 86.55 , including in the good interpretation, and in the third cycle the average value of students increases to 92

3 . In the first cycle the completeness of learning outcomes of class X students of SMK Dwi Putri Husada, Tanah Sareal District, Bogor City was $44.19 \%$ with an average value of 69.74 . Then experienced an increase of $41.85 \%$ which in the 
second cycle became $86.04 \%$ with an average of 80.20 and in the third cycle an increase of $47.21 \%$ with an average value of 89.6. This means that classical student learning research has reached an indicator of research success which is $85 \%$.

\section{REFERENCES}

[1] Suprijono,Agus.2009. Coopertaive Learning Teori dan Aplikasi Paikem. Yogyakarta: Pustaka Pelajar

[2] Fathurrahman, Muhammad. 2015. ModelModel Pembelajaran Inovatif Alternatif Desain Pembelajaran Yang Menyenangkan. Yogyakarta : Ar-Ruzz Media.

[3] Shoimin,Aris.2014. 68 model pembelajaran inovatif dalam kurikulum 2013. Yogyakarta: ArRuzz Media

[4] Dimyati, dan Mudjiono.2013. Belajar dan Pembelajaran. Jakarta: Rineka Cipta

[5] Arifin,Zainal.2016. Evaluasi Pembelajaran. Bandung: Remaja Rosdakarya.

[6] Tampubolon,Saur.2013.Penelitan Tindakan Kelas Sebagai Pengembangan Profesi Pendidik dan Keilmuan.Jakarta : Erlangga 